\title{
Strategi Guru Mengenalkan Konsep Dasar Literasi di PAUD Sebagai Persiapan Masuk SD/MI
}

\author{
Fahmi $^{\circledR}{ }^{\bowtie}$, Muhammad Syabrina ${ }^{2}$, Sulistyowati ${ }^{3}$, Saudah $^{4}$ \\ Pendidikan Islam Anak Usia Dini, Institut Agama Islam Negeri Palangaka Raya $(1,3,4)$ \\ Pendidikan Guru Madrasah Ibtidaiyah, Institut Agama Islam Negeri Palangaka Raya (2) \\ DOI: $\underline{10.31004 / \text { obsesi.v5i1.673 }}$
}

\begin{abstract}
Abstrak
Strategi guru merupakan unsur penting dalam proses pembelajaran. Mengenalkan konsep dasar literasi kepada anak usia dini sebagai bekal memasuki jenjang pendidikan selanjutnya, selain itu, anak juga dituntut paham tentang konsep literasi. Tujuan penelitian ini untuk mengetahui strategi guru untuk mengenalkan konsep dasar literasi di PAUD sebagai persiapan memasuki SD/MI, untuk mengetahui faktor yang mempengaruhi penggunaan strategi dalam mengenalkan konsep dasar literasi di PAUD. Penelitian ini menggunakan metode kualitatif dengan pendekatan deskriptif, adapun tehnik pengumpulan data menggunakan observasi, wawancara dan dokumentasi, analisis data menggunakan trianggulasi tehnik dan trianggulasi sumber. Hasil Penelitian menunjukan bahwa guru menggunakan beberapa strategi untuk mengenalkan konsep dasar literasi diantaranya strategi belajar langsung atau melalui bermain, melibatkan anak dalam kegiatan pembelajaran, bermain peran, bercerita, atau mendongeng. adapun faktor yang mempengaruhui guru untuk menggunakan staregi dalam mengenalkan konsep dasar literasi ialah karateristik peserta didik yang berbeda, kemampuan anak masih rendah, tuntutan orang tua dan adanya prasyarat untuk masuk SD/MI.
\end{abstract}

Kata Kunci: strategi guru; konsep dasar literasi

\begin{abstract}
Teacher strategy is an important element in the learning process. Introducing the basic concept of literacy to early childhood as a provision to enter the next level of education, Other than, children are also required to understand the concept of literacy. The purpose of this study was to determine the teacher's strategy to introduce the basic concepts of literacy in PAUD in preparation for entering SD/MI. to find out the factors that influence the use of strategies in introducing basic concepts of literacy in PAUD. This study uses a qualitative method with a descriptive approach, while the data collection techniques use observation, interviews and documentation, data analysis using technical triangulation and source triangulation. The results showed that the teacher used several strategies to introduce the basic concepts of literacy including direct learning strategies or through play, involving children in learning activities, role-playing, or storytelling. As for the factors that influence the teacher to use statistics in introducing the basic concepts of literacy. are the characteristics of different students, the ability of children is still low, the demands of parents, and the prerequisites to enter SD/MI.
\end{abstract}

Keywords: teacher strategy; concept basic literacy

Copyright (c) 2020 Fahmi, Muhammad Syabrina, Sulistyowati, Saudah

$\triangle$ Corresponding author:

Email Address : fahmiiainpky@gmail.com ( Palangka Raya, Indonesia )

Received 20 July 2020, Accepted 7 August 2020, Published 12 September 2020

Jurnal Obsesi : Jurnal Pendidikan Anak Usia Dini, 5(1) 2021 | 931 


\section{PENDAHULUAN}

Memasuki masa melenium ke tiga ini, yang mana arus globalisasi semakin berkembang pesat bahkan transformasi ilmu pengetahuan dan teknologi pada abad 21 ini sudah menyentuh seluruh bidang disiplin ilmu tak terkecuali bidang pendidikan. Bidang Pendidikan merupakan sektor penting dalam pembangunan negara. Berdasarkan Undangundang Sistem Pendidikan Nasional No 20 Tahun 2003, dijelaskan bahwa sistem pendidikan nasional harus mampu menjamin pemarataan kesempatan pendidikan, peningkatan mutu serta relvansi dan efesiensi manajemen pendidikan agar mampu menghadapi tantangan perubahan kehidupan secara global, nasional maupun lokal sehingga perlu penyesuaian pendidikan secara terencana, terarah dan berkesinambungan. Upaya menghadapi tantangan globasliasi terutama dalam bidang pendidikan, lembaga pendidikan memerlukan sumber daya manusia yang memiliki kompetensi dan berkontribusi dalam mengembangan keilmuaanya sesuai kompetensi yang dimiliki. Disinilah peran pendidik atau guru sangat menentukan yang mana guru tidak hanya sebagai memberikan ilmu pengetahuan akan tetapi guru juga berperan dalam membentuk perilaku atau karakter peserta didik. E.Mulyasa (2008) mengidentifikasi beberapa peran guru dalam pembelajaran yaitu, guru sebagai pendidik, pengajar, pembimbing, pelatih, panasehat, pembaharu, model, teladan, pribadi, peneliti, pendorong kreativitas, pembangkit pandangan, pekerja rutin, pemindah kemah, pembawa cerita, aktor, emansivator, evaluator, pengawet dan kulminator.

Guru sebagai unsur utama dalam proses pembelajaran dituntut profesioanal dalam melaksanakan tugasnya. Undang-Undang No 14 Tahun 2005 Tentang Guru dan Dosen, menyatakan bahwa guru adalah pendidik profesional dengan tugas utama mendidik, mengajar, membimbing, mengarahkan, melatih, menilai, dan mengevaluasi peserta didik pada pendidikan anak usia dini jalur pendidikan formal, pendidikan dasar, dan pendidikan menengah. Pada pendidikan anak usia dini guru memilki peran utama ialah sebagai tenaga profesional yang bertugas merencanakan, melaksanakan pembelajaran, dan menilai hasil pembelajaran, serta melakukan pembimbingan, pelatihan, pengasuhan dan perlindungan. Dalam melaksanakan pembelajaran, guru harus mengacu pada tujuan akhir yang harus dicapai oleh anak, yang bertitik tolak pada enam aspek perkembangan anak. (Kementerian Pendidikan dan Kebudayaan Republik Indonesia, 2014). Selanjutnya Musfiroh dalam (Suriati, 2019) bahwa terdapat enam aspek yang dikembangan pada anak usia dini meliputi aspek pengembangan pembiasaan meliputi sosial, emosi, kemandirian, moral, dan nilai-nilai agama, serta pengembangan kemampuan dasar yang meliputi pengembangan bahasa, kognitif, dan fisik motorik.

Pengenalan konsep dasar literasi merupakan salah satu upaya yang dilakukan untuk mengembangkan kemampuan kognitif dan bahasa anak yang meliputi pengenalan konsep membaca, menulis dan berhitung, sehingga anak tidak mengalami kesulitan untuk menyesuaikan yang diterapkan di sekolah lanjutan, yaitu Sekolah Dasar atau Madrasah Ibtidaiyah. Menurut Suragangga dalam Zati (2018) menyebutkan bahwa literasi dasar (basic literasi) merupakan kemampuan untuk mendengarkan, berbicara, membaca, menulis dan menghitung. Literasi juga merupakan bagian yang tidak terpisahkan dalam kehidupan seharihari maupun dalam proses pembelajaran yang mana secara tidak langsung akan termuat dalam kegiatan anak yang dilakukan dengan cara bermain sambil belajar dan belajar sembari bermain, akan. Menurut Chairilsyah kemampuan literasi yang dimiliki oleh anak dapat berpengaruh terhadap perkembangan sosial emosional, perkembangan kognitif dan bahasa anak. (Khirjan, 2020). Akan tetapi fenomena yang tampak sekarang ini sebagian besar orang tua menuntut anak agar memahami tentang konsep literasi ini tidak cukup hanya diperkenalkan melalui kegiatan bermain saja akan tetapi pembelajaran literasi yang memuat unsur membaca menulis dan berhitung dapat diwujudkan dalam pembelajaran yang terpisah tujuannya agar anak benar-benar mahir membaca, menulis dan berhitung pada saat lulus dari jenjang pendidikan anak usia dini dan dapat mudahkan anak masuk ke sekolah dasar atau madrasah. Jika merujuk pada surat edaran yang Departemen Pendidikan Nasional Direktorat 
Jenderal Manajemen Pendidikan Dasar Dan Menengah Nomor: 1839/C.C2/TU/2009 Perihal: Penyelenggaraan Pendidikan Taman Kanak-Kanak dan Penerimaan Siswa Baru Sekolah Dasar berisi tentang Pengenalan membaca, menulis dan berhitung (calistung) dilakukan melalui pendekatan yang sesuai dengan tahap perkembangan anak. Oleh karena itu pendidikan di TK tidak diperkenankan mengajarkan materi calistung secara langsung sebagai pembelajaran sendiri-sendiri (fragmented) kepada anak-anak.

Besarnya keinginan orang tua dan adanya tuntutan yang diberlakukan pada jenjang lanjutan SD/MI agar anak mampu membaca, menulis dan berhitung sangat berpengaruh terhadap program pembelajaran di PAUD khususnya pembelajaran membaca menulis berhitung. Berdasarkan hasil studi yang dilakukan oleh PIRLS (Progress in International Reading Literacy Study) di bawah naungan Asosiasi internasional yang bergerak dibidang literasi membaca untuk siswa sekolah dasar dilaksanakan pada tahun 2011. Adapun hasil penelitiannya menunjukan bahwa rata-rata kemampuan memahami bacaan siswa kelas IV SD dan MI di Indonesia memperoleh skor 428, yang masih di bawah skor rata-rata 500, dan menduduki peringkat ke 42 dari 45 negara yang diteliti. (Mullis, 2012). Berdasarkan hal tersebut, guru perlu mempersiapkan strategi yang tepat agar pembelajaran yang diberikan kepada peserta didik dapat membekali pengetahuan anak, baik secara kognitif, afektif maupun psikomotoriknya, sehingga anak mampu dan siap melangkah kejenjang pendidikan selanjutnya. Strategi juga dapat dikatakan sebagai pola dalam pelaksanaan pembelajaran yang dipilih dan digunakan guru, dan disajikan secara kontekstual, sesuai dengan karakteristik peserta didik, kondisi sekolah, lingkungan sekitar serta tujuan khusus pembelajaran yang dirumuskan. (Anitah, 2007). Adapun strategi pembelajaran anak usia dini harus mengedepankan aspek aktivitas bermain, bernyanyi, sehingga dapan mengasah otak, kecerdasan, emosi dan keterampilan fisik yang dilakukan dengan menyenangkan. (Nurmadiah, 2016). Pada dasarnya strategi yang dapat digunakan guru pada saat kegiatan pembelajaran khususnya pembelajaran membaca, menulis dan berhitung yaitu strategi yang berpusat pada anak. Strategi pembelajaran yang berpusat pada anak ciri-cirinya yaitu: materi sesuai dengan kebutuhan dan perkembangan anak, metode pembelajaran mengacu pada center of interest, media dan sumber belajar yang tersedia di lingkungan belajar, pengelolaan kelas yang bersifat demokrasi, keterbukaan, saling menghargai, kepedulian dan kehangatan. (Hasanah, 2019).

Strategi yang digunakan oleh guru untuk mengenalkan konsep literasi pada anak dapat mengacu pada Standar Tingkat Pencapaian Perkembangan Anak (STPPA) yang termuat dalam Peraturan Menteri Pendidikan dan Kebudayaan Republik Indonesia No 137 tahun 2014, maka pembelajaran calistung pada anak terbatas hanya mengenalkan konsep yaitu pada lingkup perkembangan kognitif indikator yang harus dicapai oleh anak diantaranya Mengenal pola ABCD-ABCD, Mengurutkan benda berdasarkan ukuran dari paling kecil ke paling besar atau sebaliknya, menyebutkan lambang bilangan 1-10, menggunakan lambang bilangan untuk menghitung, mencocokkan bilangan dengan lambang bilangan. Pada lingkup perkembangan bahasa Indikator yang harus dicapai oleh anak diantaranya berkomunikasi secara lisan, memiliki perbendaharaan kata, serta mengenal simbol-simbol untuk persiapan membaca, menulis dan berhitung, menyusun kalimat sederhana dalam struktur lengkap, membaca nama sendiri, menuliskan nama sendiri, memahami arti kata dalam cerita.

Hasil observasi pada 23 juli 2018 di RA Muslimun Palangka Raya, diketahui bahwa guru menggunakan kegiatan yang berariasi tanpa menyampingkan kegiatan bermain dalam proses pembelajaran yang di dalamnya termuat materi pengenalan konsep literasi yaitu yang utamnya pembelajaran membaca, menulis dan berhitung. Senada dengan hasil wawancara diperoleh informasi bahwa guru menggunakan beberapa strategi dalam proses pembalajaran terutama strategi yang mengandung unsur bermain serta menggunakan media pembelajaran, agar menghadirkan benda yang konkrit agar anak mudah memahami penjelasan dari guru, akan tetapi pembelajaran membaca, menulis dan berhitung pada anak usia dini diajarkan 
hanya pada konsep pengenalan saja, dan menggunakan benda atau alat bermain yang ada disekitar lingkungan anak, sehingga anak sudah familier dan tidak mengalami kesulitan.

Berdasarkan permasalahan di atas, maka tema penelitian yang diangkat dalam penelitian ini ialah tentang strategi guru mengenalkan konsep literasi berhitung di PAUD untuk mempersiapkan masuk SD/MI. Tujuan penelitian ini mendeskripsikan strategi guru mengenalkan konsep membaca, menulis dan berhitung pada anak usia dini sebagai persiapan masuk SD/MI. Mengetahui faktor yang mempengaruhi guru menggunakan strategi dalam mengenalkan konsep literasi pada anak sebagai persiapan masuk SD/MI. Adapun Manfaat yang didapatkan dari penelitian ini yaitu, agar guru atau pendidik memahami tentang strategi pembelajaran dan konsep mengenalkan pembelajaran membaca, menulis dan berhitung dengan memperhatikan kegiatan pembelajaran yang memuat unsur bermain, serta sesuai dengan kebutuhan dan perkembangan anak. Selain itu, agar dapat memahami faktor yang dapat mempengaruhi dalam mengenalkan konsep literasi pada anak.

\section{METODOLOGI}

Metode yang digunakan dalam penelitian ini adalah metode kualitatif pendekatan deskriptif artinya hasil dari penelitian ini disajikan dengan memaparkan data yang diperoleh dari hasil identifikasi tentang strategi guru mengenalkan konsep literasi di PAUD untuk mempersiapkan masuk SD/MI dengan mengambil objek penelitian peserta didik di RA AlMuslimun kelompok B. Tehnik pengumpulan data yang digunakan yaitu observasi, wawancara dan dokumentasi. alat yang digunakan berupa daftar observasi, dan daftar wawancara untuk mengetahui startegi yang digunakan untuk mengenalkan konsep literasi pada anak, serta dokumentasi untuk mengetahui peroses pembelajaran yang dilaksanakan pada saat guru mengenalkan konsep literasi pada anak yang termuat di dalamnya unsur membaca, menulis dan berhitung.

Tehnik analisis data yang digunakan untuk menggambarkan tentang hasil penelitian dilakukan secara terstruktur menggunakan empat konsep cara yaitu pengumpulan data, reduksi data, penyajian data dan penarikan kesimpulan. Adapun Tehnik Pemeriksaan keabsahan data berdasarkan kereteria kepercayaan, maka yang digunakan adalah trianggulasi, yaitu tehnik pemeriksaan keabsahan data yang memanfaatkan sesuatu di luar data itu untuk keperluan pengecekan atau sebagai pembanding terhadap data itu. (Moleong, 2005). Triangulasi yang akan digunakan peneliti adalah triangulasi sumber yaitu membandingkan dan mengecek baik derajat kepercayaan suatu informasi yang diperoleh melalui alat yang berbeda. Hal ini dapat dicapai dengan cara: (1) membandingkan data hasil observasi dengan wawancara, (2) membandingkan subyek dan informan, (3) membandingkan hasil wawancara dengan dokumen yang berkaitan.

Berikut akan disajikan langkah analisis data penelitian tentang strategi guru mengenalkan konsep literasi di PAUD untuk mempersiapkan masuk SD/MI

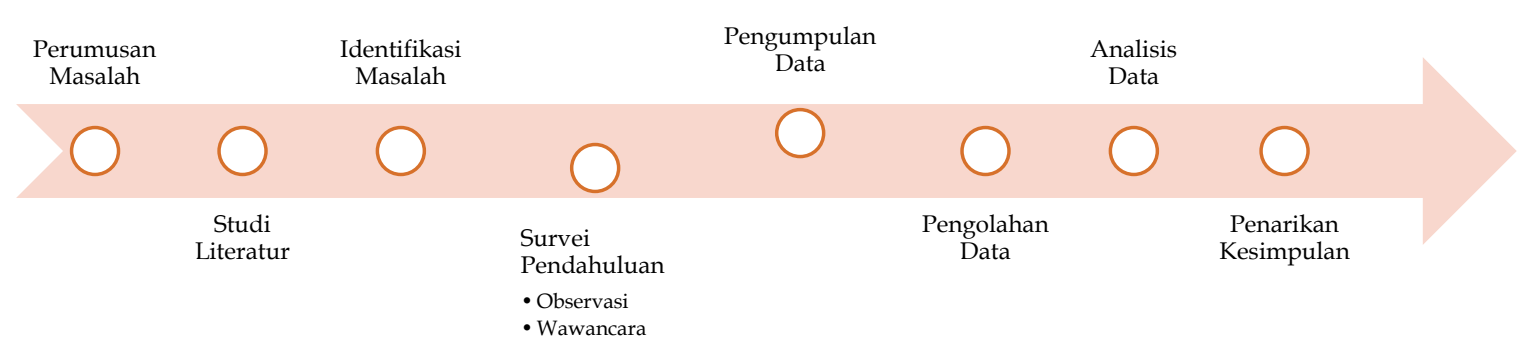

Gambar 1. Bagan Alur Penelitian 


\section{HASIL DAN PEMBAHASAN \\ Strategi Guru Mengenalkan Konsep Literasi Pada Anak Usia Dini Sebagai Persiapan Masuk SD/MI}

Guru sebagai pusat pembelajaran bagi anak tidak hanya memiliki kemampuan dalam mengajar akan tetapi harus memiliki daya kreativitas yang tinggi untuk menarik minat anak dalam belajar terutama pada pembelajaran membaca, menulis dan berhitung yang biasa dikenal dengan literasi, sebagaimana yang dilaksanakan di RA Muslimun Palangka Raya, guru merasa penting untuk mengembangkan kreativitasnya dalam membuat dan mempersiapkan kegiatan pembelajaran agar dapat memenuhi kebutuhan anak dalam pembelajaran dan menarik minat anak untuk belajar terutama dalam mengenalkan konsep literasi pada anak, guru juga mempersiapkan strategi khusus agar anak dapat dengan mudah memahami dan mengenal bentuk huruf dan bilangan, bunyi huruf dan tatacara menjumlah bilangan. ada beberapa media yang dipersiapkan guru untuk menunjang pembelajaran diantaranya kartu huruf dan angka, lembar kerja anak, papan tulis yang dapat digunakan guru untuk memberikan contoh kepada anak. selain itu, guru juga menggunakan metodemetode yang dapat mempermudah anak dalam mengingat dan menghafal huruf dan angka diantaranya dengan menggunakan metode bernyanyi, bercerita dan karyawisata.
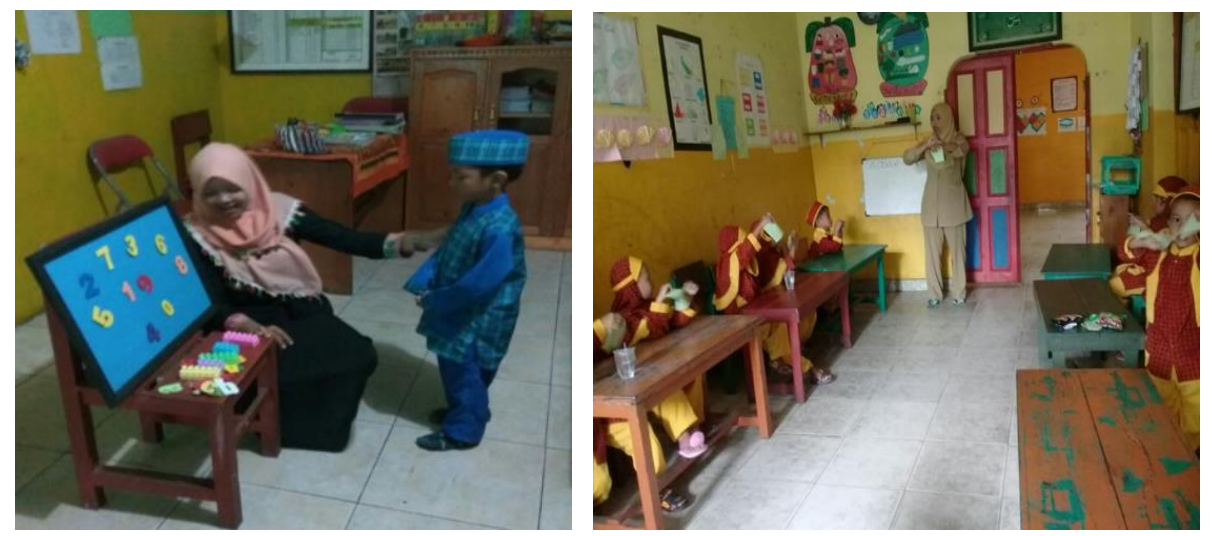

\section{Gambar 2. Kegiatan Pembelajaran dengan Strategi Melibatkan Anak dan Strategi Mendongeng}

Sebagaimana hasil observasi yang dilakukan pada bulan mei 2018 di RA Al-Muslimun Palangka Raya, dapat diketahui bahwa kegiatan pembelajaran dilaksanakan berdasarkan SOP yang disepakati oleh sekolah dan perencanaan pembelajaran yang sudah dipersiapkan untuk guru setiap hari. kegiatan pembelajaran mencakup pembiasaan-pembiasaan untuk mengembangkan karakter anak, selain itu pada kegiatan inti guru menyusun kegiatankegiatan yang menekankan pada beberapa aspek perkembangan seperti bahasa kaitannya dengan membaca atau mengenal bunyi huruf, aspek kognitif termasuk di dalamnya mengenal huruf, dan mengenal angka, aspek sosial dan emosional, agama, motorik dan seni. Dalam proses kegiatan pembelajaran guru juga menggunakan media, adapun media yang digunakan untuk mengenalkan konsep dasar literasi pada anak yaitu, papan tulis sebagai pembuka dan sebagai media mengenalkan hari, tanggal, bulan dan tahun, dan media papan tulis juga digunakan guru sebagai media untuk mengenalkan langsung cara membuat huruf, atau mengenal bentuk huruf dan angka, selain itu ada kartu bergambar yang digunakan untuk mengenal bunyi huruf dan bacaan. Berikut beberapa strategi yang digunakan guru untuk mengenalkan konsep dasar literasi pada anak usia dini.

\section{Pembelajaran Langsung/Bermain}

Pembelajaran langsung atau biasa disebut strategi belajar melalui bermain merupakan strategi yang menyajikan materi pembelajaran secara langsung kepada anak, dan anak diberikan kesempatan untuk melakukan sendiri, atau bermain sendiri dengan menggunakan 
alat permainan berupa balok, puzzle, peralatan lukis, dengan cara ini diharapkan anak dapat melakukan kegiatan secara tuntas. Adapun peran guru memfasilitasi belajar anak agar mencapai tujuan yanga telah direncanakan. (Nuraeni, 2014). Strategi berajar langsung atau bermain tidak hanya dilaksanakan di dalam ruangan (Indoor) tetapi juga di luar ruangan (Outdoor). pada saat bermain di luar ruangan anak bisa lebih berkreasi melalui bahan-bahan yang disediakan oleh alam. Bermain di luar atau outdoor dapat menciptakan kesenangan pada anak dan dapat membantu pertumbuhan dan perkembangan anak, karena dilingkungan outdoor tersedia lingkungan dan bahan bermain yang disediakan oleh alam dan anak dapat melihat setiap benda-benda yang ada disekitarnya. (Susilowati, 2014). Belajar langsung maupun belajar melalu bermain dilaksanakan sebagai upaya untuk mengenalkan konsep dasar literasi, karena media yang digunakan anak untuk kegiatan bermain terdapat unsurunsur literasi, misalnya media balok huruf, Sofiyani mengemukakan bahwa balok huruf merupakan media atau alat permainan yang berbentuk kotak atau kubus kecil yang terdiri dari 6 sisi dan setiap sisinya diberi kata dan gambar yang dapat digunakan untuk permainan mengenal huruf dan kata. (Andiyani, 2015).

Strategi ini dapat digunakan oleh guru sebagai salah satu cara untuk mengenalkan konsep dasar literasi pada anak, yang mana anak secara tidak langsung diajak untuk mengenal konsep membaca, menulis dan berhitung pada saat melakukan kegiatan bermain. Sebagaimana hasil wawancara dengan guru di RA Al-Muslimun diperoleh informasi bahwa konsep dasar literasi yang dikenalkan kepada anak, di awali dengan mengenalkan konsep membaca, menulis dan berhitung. strategi yang digunakan dalam upaya mengenalkan kosep dasar literasi ini salah satunya dengan kegiatan bermain, pada saat kegiatan bermain anak akan disajikan beberapa media yang di dalamnya mengandung unsur literasi, misal menggunakan media puzzle huruf, yang mana anak di ajak untuk menyusun huruf dan mengenal bentuk huruf dan bunyi huruf, jadi pada kegiatan ini selain bermain anak juga di ajak untuk mengembangkan pengetahuannya, jadi disini posisi guru sebagai pemberi stimulasi kepada anak, guru sesekali memberikan pertanyaan kepada anak terkait bunyi huruf atau mencari huruf yang disebutkan oleh guru.

\section{Melibatkan Anak dalam Kegiatan}

Melibatkan anak dalam kegiatan pembelajaran yang dilaksanakan di dalam kelas atau di luar kelas. keterlibatan anak dalam kegiatan di sekolah mengarah kepada adanya hubungan kerjasama antara guru dan anak. Strategi ini tidak hanya terfokus pada mengenalkan konsep dasar literasi saja akan tetapi mencakup beberapa aspek yang dapat membantu anak untuk berkembang potensi yang ada dalam dirinya baik secara fisik, sosial maupun intelektualnya. mengenalkan konsep dasar literasi pada anak usia dini dini dapat dilakukan dengan memberikan kegiatan-kegiatan yang menstimulasi interaksi verbal anak, memperkaya kosa kata, mendorong pembicaraan mengenai buku, melatih pengucapan kata, dan mengembangkan pengetahuan mengenai bahan-bahan cetak (seperti mengenalkan huruf-huruf, membiasakan anak dengan mekanisme dan tujuan dasar dari membaca sebuah bacaan). (Karima \& Kurniawati, 2020).

Upaya mengenalkan konsep literasi pada anak melibatkan anak dalam kegiatan di sekolah merupakan salah satu strategi yang digunakan guru. Sebagaimana informasi yang didapatkan dari hasil wawancara di RA Al-Muslimun, guru bersama anak membangun kerjasama agar setiap kegiatan dapat dilakukan oleh anak, dari beberapa kegiatan yang erat hubungannya dengan mengenalkan konsep dasar literasi kepada anak ialah pada awal masuk kelas, guru meminta anak untuk menghitung jumlah temannya yang hadir, atau yang tidak hadir, masuk pada kegiatan awal guru mengajak anak untuk mengingat hari dan menyebutkan nama hari, dan menuliskannya di papan tulis, sampai pada akhir kegiatan pembelajaran, itulah strategi yang digunakan agar anak dapat belajar tentang konsep dasar literasi dari beberapa kegiatan yang dilakukan di sekolah. 


\section{Bermain Peran/Bercerita/dongeng}

Mengenalkan konsep dasar literasi pada anak tidak cukup dengan menyediakan beberapa media pembelajaran, akan tetapi peran anak itu sendiri sebagai media belajar itu lebih penting, artinya anak lebih banyak terlibat ddi dalam kegiatan itu, contohnya kegiatan bermain peran, bercerita atau mendongeng. Strategi itu cukup efesien untuk melatih anak dalam berkomunikasi, mengucapkan kata dengan baik dan juga dapat melatih kecakapan berbahasa anak. Bahasa erat kaitannya dengan kemampuan litersai pada anak, dalam hal ini guru dapat melatih konsep dasar literasi pada anak melalui mendongeng atau mengajak anak bermain peran, selain itu membentuk kerangka konseptual pada pikiran anak, sehingga akan tercipta pengalaman baru yang dapat membuat anak mudah untuk memahami makna dari cerita yang sampaikan kepada anak. Dengan adanya dongeng, anak akan dapat memetakan berdasarkan mental pengalaman yang di dapat dan melihat apa yang dipikirkan setelah dongeng dibacakan dan diceritakan. (Sumaryanti, 2018). Berdasarkan hasil penelitian Ruhaena, dkk pada tahun 2014 menunjukkan bahwa di Indonesia aktivitas literasi untuk anak usia dini lebih banyak mengajar teks melalui meng-hafal huruf dan mengeja kata. cara ini merupakan cara yang kurang menyenangkan untuk anak, karena bersifat tekstua dan lebih menekankan pada pendekatan kognitif. Hal ini, berbeda dengan aktivitas literasi yang dilakukan di negara maju seperti Amerika, Inggris, dan Australia yang lebih konteks-tual dan aplikatif dalam kegiatan sehari-hari yang natural seperti membaca buku cerita dan bermain literasi yang membuat anak tertarik dan termotivasi. (Ruhaena, 2015).

Berdasarkan hasil observasi dapat diketahui bahwa guru menggunakan strategi bermain peran, mendongeng atau bercerita ini menyesuaikan dengan tema dan subtema pembelajaran, sehingga strategi ini tidak digunakan guru setiap hari, akan tetapi mekipun guru tidak melakukan kegiatan bermain peran, bercerita atau mendongeng, pada awal pembelajaran guru memepersilahkan anak atau memberikan pertanyaan kepada anak tentang pengalaman yang dia dapatkan ketika persiapan sekolah sampai menuju ke sekolah, jadi dalam posisi ini anak yang bercerita kepada guru dan teman-temannya, hal yang sama juga dilakukan guru ketika pelaksanaan recalling, guru mempersilahkan kepada anak untuk menceritakan pengalaman belajarnya pada hari itu. Dikuatkan dengan hasil wawancara bahwa, guru menggunakan strategi itu dengan tujuan anak mampu mengungkapkan gagasan yang ada dalam pikiran anak, dan melatih anak berkomunikasi dan merangkai kata atau kalimat menjadi sebuah cerita.

\section{Faktor Yang Mempengaruhi Guru Menggunakan Strategi dalam Mengenalkan Konsep Dasar Literasi di PAUD Sebagai Persiapan Masuk SD/MI \\ Karakteristik Peserta Didik}

Karakteristik peserta didik merupakan salah satu faktor yang dapat mempengaruhi dalam proses mengenalkan konsep literasi, karena pada masa usia dini anak berada dimasa perkembangan yang sangat pesat, secara umum karakteristik anak usia dini sangat berbeda dengan orang dewasa, oleh karena itu, guru juga harus memahami cara yang tepat untuk memahami setiap anak yang memiliki karakteristik berbeda pula. Karakteristik anak usia dini yang harus dipahami oleh guru atau orangg tua yaitu: 1) Anak memiliki rasa ingin tahu yang besar, 2)Anak merupakan pribadi yang unik, 3) Anak suka berfantasi dan berimajinasi, 4) Masa usia dini merupakan masa potensial untuk belajar, 5) Anak memiliki sikap egosentris, 6) Anak memiliki rentan daya konsentrasi yang pendek, 7) Anak merupakan bagian dari mahluk sosial. (Hartati, 2005). Berdasarkan adanya perbedaan karaktristik setiap anak itu, maka rangkaian kegiatan pembelajaran juga dapat menyesuaikan dengan perbedaan tersebut.

Berdasarkan hasil wawancara di RA Al-Muslimun Palangka Raya, dapat diperoleh informasi bahwa pada awal pembelajaran guru penting memahami karakteristik anak, karena anak usia dini yang masih berada pada masa perkembangan, akan mengalami maju mundur perkembangan, sehingga masing-masing anak memiliki karakteristik berbeda-beda. Tujuan guru memahami karakteristik anak, itu ada hubungannya dengan kegiatan pembelajaran 
yang akan dilaksanakan, misal dalam menentukan strategi pembelajaran, setiap anak tentu mempunyai gaya belajarnya masing-masing sehingga dalam pembelajaran, apalagi dalam mengenalkan konsep dasar literasi, guru harus memilih strategi yang tepat agar anak dapat belajar dengan nyaman dan tenang, jadi di kelas itu guru menyediakan beberapa kegiatan, dan media pembelajaran, namun yang terpenting bagi guru adalah tecapainya tujuan pembelajaran yang telah direncanakan dalam RPPH.

\section{Kemampuan Peserta Didik Masih Rendah}

Peserta didik adalah anggota masyarakat yang berusaha mengembangkan potensi diri melalui proses pembelajaran yang tersedia pada jalur, jenjang dan jenis pendidikan tertentu. (Undang-undang Sistem Pendidikan Nasional No 20 Tahun 2003). Dalam perspektif psikologi peserta didik adalah individu yang sedang berada dalam proses pertumbuhan dan perkembangan baik fisik maupun psikis menurut fitrahnya masing-masing, sebagai individu yang tengah tumbuh dan berkembang, peserta didik memerlukan bimbingan dan pengarahan yang konsisten menuju titik optimal kemampuan fitrahnya. (Desmita, 2012). Selain itu, terdapat dua hal yang perlu dipahami oleh guru terhdap peserta didik yaitu keunggulan dan kekurangannya. Jadi pada dasarnya guru harus memahami peserta didik dari segala aspek diantaranya aspek tahap perkembangannya, kemampuan, keunggulan serta kekurangannya, faktor penghambat dan faktor pendukung yang dapat mempengaruhinya. (Theresia, 2020)

Kemampuan anak memahami pembelajaran erat hubungannya dengan kemampuan proses berpikir anak atau kemampuan kognitif anak. Kemampuan kognitif merupakan suatu proses berfikir, yang diukur dari kemampuan anak dalam menghubungkan, menilai suatu kejadian atau peristiwa, kemampuan anak juga dapat dilihat pada saat anak bermain, diantaranya mengelompokkan benda yang memiliki persamaan warna, bentuk, dan ukuran, mencocokkan lingkaran, segitiga, dan segiempat serta mengenali dan menghitung angka 1 sampai 20. (Rachmat, 2017). Rendahnya kemampuan peserta didik ini juga disebabkan oleh beberapa faktor seperti lingkungan, psikologis, oleh karena itu, tetapi peran peserta didik tidak hanya dapat memperkuat dan mendukung proses pembelajaran akan tetapi peran peserta didik juga dapat memperlemah pencapaian tujuan pembelajaran.

sebagaimana di RA Al-Muslimun diketahui bahwa peserta didik dapat menjadi faktor yang menghambat guru dalam melaksanakan pembelajaran adalah kemampuan anak yang masih rendah, karena terdapat sebagian anak yang masih belum bisa menulis angka dan huruf. Hal itu lah yang menuntut guru harus lebih kreatif dalam mempersiapkan baik stratetegi, media maupun materi pembelajaran agar anak yang memiliki kemampuan rendah dapat memahami dan mengikuti pembelajaran dengan baik

\section{Harapan Orang Tua}

Menganalkan konsep literasi pada anak usia dini, yang di dalamnya termasuk kemampuan membaca, menulis dan berhitung, merupakan fenomen yang saat ini hangat diperbincangkan, karena sebagian besar orang tua memiliki tujuan untuk memasukan anaknya ke lambaga PAUD agar memiliki kemampuan membaca, menulis dan berhitung, karena orang tua mengkhawatirkan anaknya terhalang masuk sekolah lanjutan baik Sekolah Dasar (SD) maupun Madrasah Ibtidaiyah (MI), diakibatkan tidak mampu membaca, menulis, dan berhitung. Harapan yang diberikan orang tua terhadap anak nya merupakan wujud perhatian dan tanggung jawab orang tua kepada anak. Sebagaimana peran orang tua sebagai fasilitator terhadap pendidikan anak. Orang tua dapat menjadi fasilitator dalam pendidikan anak, termasuk menentukan berbagai cara untuk mendapatkan fasilitas yang dapat menunjang program belajar anak, karena peran orang tua juga dapat mempengaruhi hasil belajar anak, fasilitas yang dapat disediakan orang tua diantaranya berkenaan dengan penyediaan buku-buku ajar yang dibutuhkan peserta didik, demikian juga dengan fasilitas lainnya, seperti alat-alat tulis, tempat belajar, dan lain-lain. (Umar, 2015) 
Berdasarkan hasil wawancara dapat diketahui bahwa banyak orang tua yang berharap ketika lulus dari PAUD anak mampu menguasai keterampilan membaca, menulis dan berhitung. Harapan yang diberikan orang tua terhadap anaknya dengan tanpa alasan, mererka beranggapan bahwa jika anak terampil membaca, menulis dan behitung, akan mudah masuk ke sekolah dasar atau madrasah yang terfavorit. Beranjak dari hal itulah guru perlu membuat strategi agar harapan orang tua terhadap anaknya dapat dipenuhi. Namun dalam hal ini guru juga harus memperhatikan hal-hal yang tentunya tidak boleh dilakukan oleh guru, misal mengajarkan anak baca tulis secara langsung, memaksa anak harus bisa membaca dan menulis tanpa memikirkan psikologi dan tahap perkembangan anak, oleh karena itu, strategi yang kami persiapkan dalam kegiatan pembelajaran sangat memperhatikan karakteristik anak, kemampuan anak, dan perkembangan anak.

\section{Prasyarat memasuki SD/MI}

Strategi digunakan guru dalam mengenalkan konsep literasi pada anak erat kaitannya dengan adanya prasyarat yang ditentukan sekolah untuk peserta didik baru yang ingin masuk sekolah dasar atau madrasah. Adanya syarat tersebut dikarenakan banyaknya animo siswa dan adanya tuntutan kurikulum yang diterapkan di sekolah. Berdasarkan hasil wawancara dengan kepala sekolah MIN 1 Langkai pada sabtu 28 Juli 2018, dapat diketahui bahwa adanya syarat yang diberikan sekolah dasar atau madrasah pada awal masuk sekolah dikarenakan banyaknya animo calon siswa yang mendaftar membuat pihak sekolah dan panitia seleksi harus adil dalam menentukan kelulusan penerimaan. Hal inilah yang menjadi salah satu faktor munculnya tes seleksi di sekolah. Pihak sekolah dan panitia harus memberikan berbagai jenis tes untuk menentukan siapa yang akan diterima sebagai siswa baru, salah satunya adalah tes untuk mengetahui kemampuan calistung calon siswa baru. Dalam konteks ini, anak hanya dituntut untuk mampu minimal menuliskan nama sendiri, menulis tanggal lahir, nama orang tua, dan disuruh berhitung sederhana saja. Hasil tes akan diurutkan sesuai peringkat nilai yang diperoleh anak dan diterapkan sistem pagu, otomatis yang nilainya tinggilah yang akan diterima. Berdasarkan hal tersebut diperoleh gambaran bahwa pihak sekolah meskipun tidak menyebutkan secara terang-terangan tentang syarat kemampuan calistung ini, karena pihak sekolah dan panitia memberikan berbagai macam tes, namun tetap tidak bisa dipungkiri bahwa calistung menjadi bagian yang dinilai saat tes seleksi masuk SD/MI.

Jika merujuk hal tersebut di atas maka guru perlu memberikan bekal pengetahuan tentang konsep literasi pada anak, agar ketika anak masuk sekolah dasar atau madrasah dapat menyesuaikan pembelajaran yang lebih mengutamakan penalaran dan analisis dan pengembangan gagasan, karena pada usia sekolah dasar anak memasuk tahap perkembangan opersional konkrit Sebagaimana ungkapan piaget bahwa pada usia sekolah dasar yaitu usia 7-11 tahun anak berada pada tahap perkembangan operasional konkrit, pada masa ini anak mulai mampu berpikir logis untuk menggantikan cara berpikir pada tahap sebelumnya yang masih bersifat primitif, intuitif dan imajinatif, namun membutuhkan contoh-contoh konkrit. Implikasi dari teori Piaget tersebut menunjukkan bahwa pembelajaran di SD harus menggunakan pendekatan melalui kegiatan yang nyata atau konkret. (Asiah, 2018).

\section{SIMPULAN}

Mengenalkan konsep dasar literasi pada anak usia dini di lembaga PAUD, harus merujuk kepada indikator perkembangan anak. Strategi yang digunakan guru diantaranya, pembelajaran langsung, atau belajar melalui bermain, melibatkan anak dalam kegiatan bermain dan belajar, bercerita atau mendongeng dapat dijadikan kontribusi dalam mengenalkan konsep dasar literasi pada anak. Adapun faktor-faktor yang mengharuskan guru menggunakan strategi dalam mengajar ialah perbedaan karakteristik anak, kemampuan anak masih rendah, dan harapan orang tua yang menginginkan anaknya memahami konsep literasi pada saat lulus dijenjang PAUD. 


\section{UCAPAN TERIMA KASIH}

Terimakasih penulis ucapkan kepada tim peneliti, yang telah meluangkan waktu, dan tenaganya untuk melakukan penelitian, hingga tersusunnya artikel ini. selain itu ucapan terimakasih juga kepada pengelola jurnal obsesi yang berkenan menerbitkan artikel hasil penelitian ini.

\section{DAFTAR PUSTAKA}

Andiyani, S. L. (2015). Penggunaan Media Balok Huruf Pada Kemampuan Mengenal Huruf Anak. Jurnal Pendidikan Anak, 1(4).

Anitah, S. (2007). Strategi Pembelajaran. Jakarta: Universitas Terbuka.

Asiah, N. (2018). Pembelajaran Calistung Pendidikan Anak Usia Dini Dan Ujian Masuk Calistung Sekolah Dasar Di Bandar Lampung. Terampil : Jurnal Pendidikan Dan Pembelajaran Dasar, 5(1), 19. https://doi.org/10.24042/terampil.v5i1.2746

Desmita. (2012). Psikologi Perkembangan Peserta Didik. PT Remaja Rosdakarya.

E.Mulyasa. (2008). Standar Kompetensi dan Sertifikasi Guru. In Standar Kompetensi dan Sertifikasi Guru (Vol. 3). Bandung: Remaja Rosdakarya.

Hartati, S. (2005). Perkembangan Belajar Anak Usia Dini. In Jakarta: Depdiknas.

Hasanah, U. (2019). Strategi Pembelajaran Aktif Untuk Anak Usia Dini. INSANIA : Jurnal Pemikiran Alternatif Kependidikan, 23(2), 204-222. https://doi.org/10.24090/insania.v23i2.2291

Karima, R., \& Kurniawati, F. (2020). Kegiatan Literasi Awal Orang Tua pada Anak Usia Dini. Al-Athfal : Jurnal Pendidikan Anak, 6(1), 69-80. https://doi.org/10.14421/al-athfal.2020.61-06

Khirjan, N. dan D. Y. (2020). Jurnal Obsesi : Jurnal Pendidikan Anak Usia Dini Literasi Berbahasa Indonesia Usia Prasekolah: Ancangan Metode Dia Tampan dalam Membaca Permulaan Abstrak. 4(1), 434-441. https://doi.org/10.31004/obsesi.v4i1.372

Moleong, L. J. (2005). Metodologi Penelitian Kualitatif,. Bandung: Remaja Rosdakarya.

Mullis, I. V. S., Martin, M. O., Foy, P., \& Drucker, K. T. (2012). PIRLS 2011 International Results in Reading. In TIMSS \& PIRLS International Study Center. https://doi.org/10.1097/01.tp.0000399132.51747.71

Nuraeni, N. (2014). Strategi Pembelajaran Untuk Anak Usia Dini. Prisma Sains : Jurnal Pengkajian Ilmu Dan Pembelajaran Matematika Dan IPA IKIP Mataram, 2(2), 143. https://doi.org/10.33394/jps.v2i2.1069

Nurmadiah, N. (2016). Strategi Pembelajaran Anak Usia Dini. Al-Afkar : Jurnal Keislaman \& Peradaban, 3(1), 1-28. https:// doi.org/10.28944/afkar.v3i1.101

Permendikbud No. 137 Tahun 2014.

Rachmat, F. (2017). Kontribusi Permainan Konstruktivis (Media Balok) Dengan Peningkatan Kemampuan Kognitif. JPUD - Jurnal Pendidikan Usia Dini, 11(2), 238-251. https://doi.org/10.21009/jpud.112.04

Ruhaena, L. (2015). Model Multisensori: Solusi Stimulasi Literasi Anak Prasekolah. Jurnal Psikologi, 42(1), 47. https://doi.org/10.22146/jpsi.6942

Sumaryanti, L. (2018). Membudayakan Literasi Pada Anak Usia Dini Dengan Metode Mendongeng. $A L-$ ASASIYYA: Journal Of Basic Education, 3(1), 117. https://doi.org/10.24269/ajbe.v3i1.1332

Suriati, S., Kuraedah, S., Erdiyanti, E., \& Anhusadar, L. O. (2019). Meningkatkan Keterampilan Motorik Halus Anak melalui Mencetak dengan Pelepah Pisang. Jurnal Obsesi : Jurnal Pendidikan Anak Usia Dini, 4(1), 211. https://doi.org/10.31004/obsesi.v4i1.299

Susilowati, R. (2014). Strategi Belajar Out Door Bagi Anak PAUD. Thufula: Jurnal Inovasi Pendidikan Guru Raudhatul Athfal, 2(1), 65-82.

Theresia, A. sum dan T. E. G. M. (2020). Kompetensi Pedagogik Guru PAUD dalam Perencanaan dan Pelaksanaan Pembelajaran. Jurnal Obsesi: Jurnal Pendidikan Anak Usia Dini, 4(2), 543. https://doi.org/10.31004/obsesi.v4i2.287

Umar, M. (2015). Peranan Orang Tua Dalam Peningkatan Prestasi Belajar Anak. JURNAL EDUKASI: Jurnal Bimbingan Konseling, 1(1), 20. https:// doi.org/10.22373/je.v1i1.315

Undang-Undang No 14 Tentang Guru dan Dosen, Pemerintah Indonesia (2005).

Undang-undang Sistem Pendidikan Nasional No 20 Tahun 2003, Kemendikbud (2003).

Zati, V., D., A. (2018). Upaya Untuk Meningkatkan Minat Literasi Anak Usia Dini. Bunga Rampai Usia Emas, $4(1)$, 18-21. https://jurnal.unimed.ac.id/2012/index.php/jhp/article/viewFile/11539/10110 